Tersedia Online di http://journal2.um.ac.id/index.php/jmsp/

ISSN Online : 2541-4429

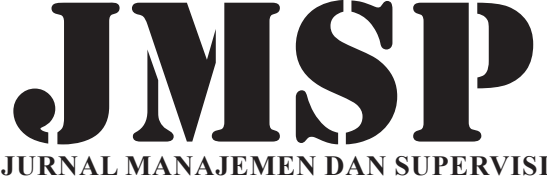

PENDIDIKAN

\title{
Kebijakan Sistem Zonasi dalam Perspektif Pendidikan
}

\author{
Gunarti Ika Pradewi; Rukiyati
}

\author{
Magister Manajemen Pendidikan, Universitas Negeri Yogyakarta \\ Filsafat dan Sosiologi Pendidikan, Universitas Negeri Yogyakarta \\ Jalan Colombo No. 1 Caturtunggal Depok Daerah Istimewa Yogyakarta Indonesia \\ gunartiikapradewi@gmail.com
}

\begin{abstract}
The purpose of this study was to find out about school attendance zones system policies in the educational perspective in Indonesia. This is a qualitative research using phenomenology method. The perspective in this study is the perspective of teachers and principals from a favorite and unfavorite school. The results of the study show the perspectives of the teachers and principals about school attendance zones are: (1) facilitating access to education services, (2) equalizing school quality, (3) reducing school quality, (4) it is not suitable at high school level (5) restricting students from choosing schools, (6) zoning policies must be accompanied by equal distribution of educational facilities and infrastructure, and (7) damaging diversity.
\end{abstract}

Keywords: Education Policy; School Attendance Zone; Pupils Personel Administration

\begin{abstract}
Abstrak: Tujuan dari penelitian ini ialah untuk mengetahui tentang kebijakan sistem zonasi dalam perspektif pendidikan di Indonesia. Penelitian dilakukan dengan menggunakan pendekatan kualitatif, metode fenomenologi. Perspektif yang diangkat ialah perspektif guru dan kepala sekolah dari SMA favorit dan tidak favorit. Hasil penelitian menunjukkan perspektif para guru dan kepala sekolah tentang zonasi meliputi: (1) zonasi memudahkan akses layanan pendidikan, (2) zonasi memeratakan kualitas sekolah, (3) zonasi menurunkan kualitas sekolah, (4) zonasi tidak cocok ditetapkan di tingkat SMA, (5) sistem zonasi membatasi siswa memilih sekolah, (6) kebijakan zonasi harus disertai pemerataan sarana dan prasarana pendidikan, dan (7) zonasi merusak kebhinekaan.
\end{abstract}

Kata Kunci: Kebijakan Pendidikan; Sistem Zonasi; Manajemen Peserta Didik

Kebijakan sistem zonasi merupakan kebijakan dalam rangka manajemen peserta didik yang mulai diberlakukan pada tahun ajaran 2017/2018. Kebijakan ini dituangkan melalui Permendikbud Nomor 17 Tahun 2017 tentang penerimaan peserta didik baru pada TK, SD, SMP, SMA, SMK atau bentuk lain yang sederajat. Seiring berjalanya waktu kebijakan tersebut diperbaharui. Pada tahun 2018 zonasi diatur dalam Permendikbud Nomor 14 Tahun 2018 tentang penerimaan peserta didik baru pada TK, SD, SMP, SMA, SMK atau bentuk lain yang sederajat . Sedangkan untuk tahun ajaran 2019/2020 kebijakan ini tertuang dalam Permendikbud Nomor 51 Tahun 2018 tentang penerimaan peserta didik baru pada TK, SD, SMP, SMA dan SMK yang diperbaharui kembali menjadi Permendikbud Nomor 20 Tahun 2019 tentang perubahan atas Permendikbud Nomor 51 Tahun 2018. Tujuan Permendikbud yang baru ialah mendorong peningkatan akses layanan pendidikan (Permendikbud Nomor 51 Tahun 2018 tentang penerimaan peserta didik baru pada TK, SD, SMP, SMA dan SMK pasal 3 ayat 1). Dengan demikian dapat dikatakan fokus utama dari kebijakan zonasi ialah pemerataan akses layanan pendidikan.

Selain pemerataan akses, masalah yang ingin diselesaikan oleh kebijakan ini ialah pemerataan kualitas pendidikan. Dari kebijakan yang dikeluarkan, mendikbud ingin agar semua sekolah menjadi sekolah favorit (Pratama, 2017). Dengan kata lain kebijakan zonasi dipandang sebagai sulusi untuk menyelesaikan dua maslaah pokok pendidikan, yaitu pemerataan akses dan kualitas pendidikan. Pada hakikatnya pemerataan pendidikan memiliki dua dimensi yaitu keadilan dan inklusi (OECD, 2008:2). Keadilan berkaitan dengan keadaan pribadi dan sosial siswa yang seharusnya tidak mempengaruhi kesempatan dalam menjalani pendidikan. Sedangkan inklusi berkaitan dengan persamaan standar 
pendidikan untuk semua. Praktiknya pemerataan pendidikan dipengaruhi oleh dua faktor yaitu penawaran dan permintaan (Cummings, 2008:66). Penawaran berada di tangan pemerintah sebagai otoritas publik yang menyediakan pendidikan. Hal ini seringkali dipengaruhi kebijakan yang dibuat pemerintah. Sementara permintaan datang dari masyarakat yang merupakan pengguna layanan pendidikan. Oleh karena itu, untuk mencapai pemerataan pendidikan diperlukan keseimbangan antara penawaran dan permintaan. Salah satu langkah yang yang diambil pemerintah saat ini adalah dengan menerapkan kebijakan sistem zonasi.

Penerapan kebijakan sistem zonasi dalam PPDB diatur dalam Permendikbud No. 14 tahun 2018. Dalam peraturan tersebut disebutkan sekolah wajib menerima paling sedikit $90 \%$ siswa yang berdomisili di zona sesuai ketentuan pemerintah daerah. Hal ini berati sekolah menerima siswa yang bertempat tinggal dekat dengan sekolah. Dengan kata lain skema zonasi memungkinkan siswa untuk memilih bersekolah di dekat rumahnya (Mandic, et.al., 2017:1). Hal tersebut membuat siswa tidak perlu pergi jauh dari lingkunganya untuk mendapatkan pendidikan.

Namun demikian kebijakan zonasi ini berbeda dengan harapan masyarakat pada umumnya. Hal ini karena masyarakat menginginkan sekolah berkualitas bagi anak-anaknya. Seperti yang dikemukakan dalam penelitian yang dilakukan oleh Andini (2009) bahwa dalam memilih sekolah hal pertama yang paling menentukan ialah kualitas sekolah dan lokasi menjadi pertimbangan yang terakhir. Selanjutnya, sekolah yang berkualitas oleh masyarakat biasa dilabeli sebagai sekolah favorit. Berdasarkan hasil penelitian Amirin, dkk. (2016:1) menunjukkan faktor utama dalam memilih sekolah ialah tingkat kefavoritan sekolah. Faktor tersebut bahkan mengalahkan faktor lain seperti fasilitas dan guru. Fakta tersebut menunjukkan adanya perbedaan antara masyarakat dan pemerintah melalui kebijakan sistem zonasi dalam hal pemilihan sekolah. Bukan hanya masyarakat, namun sekolah juga tidak bisa memilih siswa yang diinginkan.

Sekolah unggulan atau yang biasa masyarakat labeli dengan sekolah favorit memiliki passing grade yang tinggi. Laras (17 Juli 2018) mengungkapkan: di DKI Jakarta misalnya, SMAN 8, SMAN 28, dan SMAN 81 merupakan tiga sekolah" yang konsisten dengan passing grade tertinggi, baik untuk jurusan IPA maupun IPS. Angka nilai minimal untuk diterima di tiga SMA negeri unggulan tersebut di atas 90. Bahkan, pada PPDB 2017, sebanyak 10 SMA negeri jurusan IPA dengan passing grade tertinggi memiliki nilai minimal di atas 90 ".

Fakta tersebut menunjukkan dalam menyeleksi siswa untuk diterima, sekolah favorit melakukan penyeleksian terhadap nilai-nilai siswa. Di sisi lain hal itu mendukung bukti bahwa dalam menentukan sekolah masyarakat mengutamakan kualitas sekolah. Dengan demikian kebiasaan ini jauh berbeda dengan sistem zonasi yang mengutamakan wilayah zona pendaftar dibandingkan dengan nilai yang dimiliki calon siswa. Kondisi yang demikian sejatinya tidak hanya dialami oleh siswa SMA di Indonesia saja, tetapi jauh sebelum itu siswa SMA di Jepang juga terkena sistem zonasi. Namun demikian hasil riset dari Akabayashi (2006) menunjukkan implementasi sistem zonasi meningkatkan kualitas pendidikan di sekolah-sekolah perkotaan dengan meningkatnya pilihan, akan tetapi kontribusinya terhadap prestasi rata-rata siswa sangat kecil dibandingkan dengan upaya penyaringan siswa yang ditingkatkan. Hal ini berarti implementasi sistem zonasi meningkatkan kualitas sekolah namun kurang berdampak pada peningkatan prestasi siswa.

Atas dasar alasan yang dikemukakan di atas, peneliti merasa perlu mengetahui lebih lanjut tentang kebijakan sistem zonasi dalam perspektif pendidikan di Indonesia Untuk itu peneliti mengajukan pertanyaan: Bagaimana tanggapan Bpk/Ibu terhadap sistem zonasi dalam perspektif pendidikan di indonesia? Perspektif yang dipakai dalam konteks penelitian ini adalah perspektif dari guru dan kepala sekolah dalam menjalankan kebijakan zonasi. Hal ini karena guru merupakan pihak yang secara langsung berhadapan dengan para siswa hasil kebijakan zonasi. Selain itu perubahan masukan input siswa dari kebijakan zonasi ini tentu merubah cara dan proses manajemen peseta didik yang dilakukan oleh kepala sekolah. Terutama terkait menjaga dan meningkatkan kualitas sekolahnya. 


\section{METODE}

Penelitian ini menggunakakan pendekatan penelitian kualitatif dengan metode fenomenologi. Metode penelitian fenomenologi dipilih karena dengan metode ini memungkinkan peneliti untuk menggali dan mendeskripsikan pemaknaan umum sejumlah individu tentang pengalaman terkait suatu fenomena atau konsep (Creswell, 2015:105). Hal ini sesuai dengan pertanyaan bagaimana tanggapan $\mathrm{Bpk} / \mathrm{Ibu}$ terhadap sistem zonasi dalam perspektif pendidikan di indonesia?.

Pengumpulan data dilakukan melalui wawancara mendalam. Wawancara dilakukan kepada guruguru dan kepala sekolah di dua jenis sekolah yang secara umum oleh masyarakat dikenal dengan sekolah favorit dan sekolah tidak favorit. Sekolah favorit diwakili oleh SMA Cerdas, sedangkan SMA tidak favorit diwakili oleh SMA Berbakat. Informan yang berasal dari SMA Cerdas oleh peneliti diberi kode C. Artinya apabila informan tersebut ialah guru maka kode informanya adalah GC. Disisi lain apabila informan merupakan kepala sekolah maka kode yang peneliti berikan ialah KSC. Sedangkan untuk informan dari SMA Berbakat peneliti memberikan kode B. Sehingga GB merupakan kode dari guru SMA Berbakat dan KSB merupakan kode dari kepala SMA Berbakat.

Proses pengumpulan data dilakukan sejak bulan November 2018 hingga bulan Januari 2019. Selama penelitian selain melakukan pengumpulan data peneliti juga melakukan pengujian keabsahan data penelitian melalui triangulasi dan pemeriksaan anggota. Triangulasi pada dasarnya ialah teknik pengecekan data dari sumber yang diteliti (Sugiyono, 2012:327). Oleh karena itu dalam penelitian ini peneliti juga melakukan pengecekan data yang diperoleh dari para informan. Selain itu peneliti juga melakukan pemeriksaan anggota yaitu dengan meminta para informan untuk membaca dan memeriksa naskah dari peneliti (Creswell, 2015: 351). Dengan kata lain peneliti menemui para informan untuk membaca dan memeriksa transkip yang peneliti buat. Sehingga ada kesepemahanan anatara peneliti dan informan dalam hal data yang diperoleh.

Selanjutnya analisis data penelitian dilakukan dengan mengikuti langkah-langkah yang dikemukakan oleh Creswell (2015: 254-265) meliputi: mengorganisasikan data, membaca dan mebuat memo, mendeskripsikan data, mengklasifikasikan data, menafirkan data, dan menyajikan data. Pertama, pada tahap mengorganisasikan data peneliti membuat file untuk menyimpan rekaman wawancara dan membuat transkip. File yang peneliti buat diendakan antara sumber dari SMA Cerdas dan SMA Berbakat. Kedua, kegiatan membaca dan membuat memo dilakukan untuk membuat penanda terhadap transkip-transkip yang dibuat. Pada memo ini peneliti juga menuliskan tema yang muncul. Ketiga, peneliti mendeskripsikan data secara detail terhadap tema dan temuan yang diperoleh. Keempat, peneliti mengklasifikasikan data, karena data yang diperoleh dari hasil wawancara maka peneliti mengklasifikasikan dengan membuat kode untuk penyajian data. Misalnya kode (W/GB1/ 1 Januari 2019) maka uraiananya ialah:

$$
\begin{aligned}
& \mathrm{W}=\text { data wawancara } \\
& \mathrm{GB}=\text { Guru SMA Berbakat } \\
& 1=\text { kode nama guru } \\
& 1 \text { Januari } 2019=\text { tanggal wawancara. }
\end{aligned}
$$

Kelima, peneliti melakukan penafsiran data dengan membahas data dengan literatur dan hasil riset yang dilakukan oleh ilmuan terdahulu. Tahap keenam peneliti melakukan penyajian data. Dalam menyajikan data peneliti melakukan pengelompokan terhadap data-data yang temanya sesuai dan terkait satu sama lain.

\section{HASIL DAN PEMBAHASAN}

Pemberlakuan sistem zonasi oleh pemerintah yang dilakukan sejatinya bertujuan untuk memeratakan akses maupun kualitas pendidikan. Perspektif para pelaku pendidikan dalam hal ini guru dan kepala sekolah tentang zonasi meliputi: (1) zonasi memudahkan akses layanan pendidikan, (2) zonasi memeratakan kualitas sekolah, (3) zonasi menurunkan kualitas sekolah, (4) zonasi tidak cocok 
ditetapkan di tingkat SMA, (5) sistem zonasi membatasi siswa memilih sekolah, (6) kebijakan zonasi harus disertai pemerataan sarana dan prasarana pendidikan, dan (7) zonasi merusak kebhinekaan.

\section{Zonasi Memudahkan Akses Layanan Pendidikan}

Salah satu tujuan dibentuknya kebijakan zonasi ialah untuk memeratakan akses layanan pendidikan. Dalam perspektif pelaku pendidikan, kepala SMACerdas mengungkapkan "dari sudut pandang perspektif pendidikan, kebijakan zonasi bagus karena untuk memudahkan akses masyarakat dalam bersekolah. Masyarakat bisa bersekolah di sekolah yang ada di lingkunganya". Pendapat tersebut menegaskan bahwa dengan menerapkan sistem zonasi memberikan kemudahan akses pendidikan bagi masyarakat.

Sistem zonasi tidak hanya memberikan kemudahan akses layanan pendidikan, tetapi juga menguntungkan siswa karena bisa menghemat waktu dan biaya untuk bersekolah. Hal ini karena siswa bisa bersekolah di dekat tempat tinggalnya. Pernyataan tersebut sesuai dengan hasil penelitian dari Mandic, et.al. (2017:1) yang menjelaskan bahwa skema zonasi sekolah mampu memberikan kenyamanan bagi siswa untuk bersekolah di sekolah yang dekat dengan rumahnya. Disamping itu, Saporito (2017) menyatakan sebenarnya asumsi penerapan zonasi ini ditujukan untuk meminimalkan biaya transportasi. Dari dukungan dua ilmuan itu maka dapat dikatakan bahwa zonasi selain memberikan kemudahan akses layanan pendidikan kepada siswa di sekitar sekolah, juga meminimalkan biaya transportasi bagi siswa.

\section{Zonasi Memeratakan Kualitas Sekolah}

Perspektif lain selain memudahkan akses layanan pendidikan, zonasi juga dipandang mampu memeratakan kualitas sekolah. Hal ini tidak lepas dari variasi input siswa yang diterima oleh sekolah. Siswa yang diterima lebih variatif karena sekolah hanya menerima siswa yang berasal dari zona sekolah. Sehingga mau tidak mau, bagaimanapun keadaan siswa, asalkan ia berasal dari zona sekolah maka ia dapat diterima. Hal tersebut menyiratkan bahwa yang dimaksud pemerataan kualitas sekolah melalui 2 hal: pertama setiap sekolah memiliki kesempatan untuk memeroleh input siswa yang unggul. Kedua, dengan variasi siswa yang dihasilkan maka dapat menghilangkan label sekolah favorit yang selama ini menjadi pengkastaan dalam dunia pendidikan.

Terdapat dua perspektif pemerataan kualitas sekolah dalam zonasi meliputi: pertama, setiap sekolah memiliki kesempatan untuk memeroleh input siswa yang unggul. Kedua, dengan variasi siswa yang dihasilkan maka dapat menghilangkan label sekolah favorit yang selama ini menjadi pengkastaan dalam dunia pendidikan. Pernyataan tersebut sejalan dengan apa yang diungkapkan oleh Safarah \& Wibowo (2018:206) dalam tulisanya menyebutkan "program zonasi sekolah menjadi salah satu program yang efektif dari pemerintah dalam mewujudkan pemerataan pendidikan di Indonesia". Dengan demikian dapat dikatakan zonasi menjadi alat yang efektif untuk pemerataan kualitas pendidikan terutama terkait dengan pemerataan input siswa.

\section{Zonasi Menurunkan Kualitas Sekolah}

Berbeda dengan perspektif sebelumnya, yang memandang zonasi bisa memeratakan kualitas pendidikan, perspektif ketiga sebaliknya, memandang zonasi menurunkan kualitas sekolah. Penurunan kualitas sekolah tersebut terjadi karena sekolah tidak lagi bersaing menjadi sekolah favorit, seperti yang diungkapkan GC4 berikut: "Ditetapkanya sistem zonasi membuat sekolah menjadi sama. Jika semua sekolah sama maka dikhawatirkan tidak memotivasi sekolah untuk menjadi unggulan atau favorit"

Mendukung pernyataan guru sebelumnya, guru khawatir akan prestasi sekolah yang menurun akibat pemberlakuan zonasi. Dari pernyataan guru SMA favorit tersebut dapat ditarik benang merah bahwa guru SMA favorit khawatir apabila pemberlakuan sistem zonasi mempengaruhi mutu sekolah, terutama berkaitan dengan input sekolah. Hal ini terjadi karena sistem zonasi lebih memprioritaskan wilayah tempat tinggal dibandingkan prestasi siswa. Sehingga sekolah favorit tidak bisa menyeleksi siswa yang berprestasi.

Pandangan bahwa zonasi menurunkan kualitas sekolah muncul dari pandangan guru di SMA Cerdas. Hal ini karena sistem zonasi lebih memprioritaskan wilayah tempat tinggal dibandingkan prestasi siswa. Sehingga sekolah favorit tidak bisa menyeleksi siswa yang berprestasi. Padahal terkait mutu sebuah 
sekolah Perdu \& Sheetz (2008:70-72) menguraikan empat langkah untuk membentuk mutu. Empat langkah tersebut kemudian peneliti adopsi dalam konteks membentuk mutu sebuah sekolah, meliputi: pertama, manajemen sekolah harus memahami harapan dari stakeholder terutama dalam hal manajemen humas dan pelayanan. Kedua, manajemen di tingkat sekolah harus mampu mendesain produk dan layanan yang sesuai dengan keinginan stakeholder. Ketiga, memberikan layanan dan memfasilitasi dengan baik. Keempat, menjalin komunikasi dengan stakholder sekolah. Dengan memperhatikan langkah langkah tersebut, seharusnya sekolah tidak perlu khawatir dengan input siswa yang bervariatif.

Disisi lain penelitian Ferry (2018) menunjukkan bahwa dalam meningkatkan mutu lulusah hal yang bisa dilakukan oleh sekolah meliputi: pertama, perencanaan program yang diarahkan pada SKL dan didasari evaluasi diri sekolah dan survei kepuasan masyarakat. Kedua pelaksanaan program dengan dukungan aspek sarana dan prasarana, serta pelibatan orang tua dalam pelaksanaan program. Ketiga melakukan monitoring dan evaluasi terhadap program peningkatan mutu. Dengan demikian dapat dikatakan apapun inputnya asalkan proses yang dilaluinya baik maka akan menghasilkan output yang baik pula. Terlebih menurut Raharjo \& Yuliana (2016:203) "kepemimpinan kepala sekolah merupakan indikator yang paling utama dalam mewujudkan sekolah unggul yang menyenangkan" dengan demikan fakor input siswa sejatinya tidak terlalu berpengaruh dalam menyelenggarakan pendidikan yang unggul dan favorit.

\section{Zonasi Tidak Cocok Ditetapkan di Tingkat SMA}

Perspektif keempat menyebutkan bahwa sistem zonasi tidak cocok diterapkan di tingkat SMA. Hasil lapangan menunjukkan bahwa kebijakan zonasi baik diterapkan unuk level sekolah dasar atau sekolah menengah pertama. Kalau untuk level sekolah menengah atas tidak tepat". Beberapa guru berpendapat sistem zonasi lebih cocok diterapkan untuk sekolah dasar dan sekolah menengah pertama. Pendapat tersebut tentu bertolak belakang dengan praktik pelaksanaan sistem zonasi di negara-negara lain. Di Jepang misalnya Sieja (2017) menjelaskan sistem zonasi sekolah mengatur siswa-siswi dari lingkungan tertentu untuk bersekolah di sekolah umum baik tingkat SD, SMP atu SMA. Dengan demikian dapat dikatakan pelaksanaan zonasi di Indonesia baru dilaksanakan di tingkat SMA karena kebijakan ini merupakan kebijakan baru dan dilaksanakan secara bertahap.

\section{Sistem Zonasi Membatasi Siswa Memilih Sekolah}

Inti dari sistem zonasi ialah sekolah hanya boleh menerima siswa yang bertempat tinggal di lingkungan sekolah. Bukan hanya sekolah yang dibatasi, tetapi siswa juga dibatasi untuk mendaftar dan memilih sekolah yang dekat dengan tempat tinggalnya. Menurut data lapangan, siswa tidak lagi bebas memilih sekolah sesuai keinginan, tetapi harus yang dekat dengan sekolahnya. Sistem zonasi dirasa kurang cocok, itu membuat anak bangsa menjadi terkotak-kotak, meskipun tujuanya dengan sistem ini orang tua menjadi irit untuk transport, tapi mereka menjadi terampas untuk bisa memilih sehingga bisa disimpulkan bahwa zonasi membatasi siswa untuk memilih sekolah dan hal ini bertentangan dengan asas demokrasi yang berlaku di Indonesia.

Penerpan sistem zonasi dianggap membatasi siswa untuk memilih sekolah dan bertentangan dengan asas demokrasi yang berlaku di Indonesia. Sejalan dengan itu, Bunar (2010:68) menyebutkan, sistem zonasi telah mengunci kesempatan bagi siswa untuk memilih sekolah di tempat yang berbeda dengan tempat tinggalnya. Hal ini mungkin terjadi mengingat zonasi ingin memeratakan pendidikan siswa di sekitar sekolah.

\section{Kebijakan Zonasi Harus Disertai Pemerataan Sarana dan Prasarana Pendidikan}

Pemerataan akses layanan pendidikan yang menjadi tujuan sistem zonasi hendaknya juga disertai pemerataan sarana prasarana pendidikan. Hal tersebut senada dengan kondisi di lapangan bahwa niat pemerintah untuk percepatan pemerataan dirasa cukup bagus karena berkaitan dengan infrastruktur di sekolah disamakan dulu sehingga apabila menginginkan adanya pemerataan sarana prasarana pendidikan untuk mendukung pemerataan kualitas pendidikan bisa melalui sistem zonasi akan tetapi juga disertai upaya pemerataan sarana prasana.

Zonasi dipandang bisa efektif apabila disertai pemerataan sarana prasarana pendidikan untuk 
mendukung pemerataan kualitas pendidikan. Sejalan dengan hal tersebut, penelitian Nepal (2019) menunjukkan bahwa kualitas udara yang bersih dan baik, cahaya yang baik, lingkungan nyaman, aman, usia dan kondisi bangunan, kualitas pemeliharaan dapat memengaruhi kesehatan, keselamatan serta kondisi psikologis siswa. Lebih lanjut ia menguraikan Pembuat kebijakan harus memperhatikan hubungan antara fasilitas Infrastruktur sekolah dan pembelajaran dan prestasi siswa. Disisi lain penelitian yang dilakukan Liu (2017) menyebutkan baik jumlah dana maupun jumlah guru memang menyebabkan banyak ketidaksetaraan di sekolah yang berbeda. Artinya, keberadaan sarana prasarana sekolah memiliki kontribusi terhadap pemerataan kualitas sekolah. Dari dua penelitian tersebut maka dapat disimpulkan bahwa pemerataan sarana fasilitas pendidikan dapat meningkatkan mutu pendidikan.

\section{Zonasi Merusak Kebhinekaan}

Pemberlakuan sistem zonasi, di satu sisi ingin mempermudah akses layanan pendidikan bagi masyarakat sekitar sekolah, di sisi lain membuat masyarakat menjadi terkelompok dalam lingkunganya masing-masih. Hal inilah yang membuat zonasi dipandang merusak kebhinekaan. Hal lain yang sejalan yaitu bahwasannya kebijakan zonasi merusak kebhinekaan karena komposisi siswa di sekolah hanya siswa-siswi yang berasal dari lingkungan sekolah saja yang mana sistem ini dirasa bertolak belakang dengan tema multikultural atau kebhinekaan yang diangkat oleh pemerintah. Padahal tema tersebut muncul dan diaplikasikan dalam pendidikan.

Beberapa guru menganggap sistem zonasi bertolak belakang dengan tema multikultural atau kebhinekaan yang diangkat oleh pemerintah. Padahal tema tersebut muncul dan diaplikasikan dalam pendidikan. Menurut hemat peneliti, sebenarnya berbeda antara multikultural yang diangkat dalam pendidikan dengan multikulturalisme yang hilang dari sistem zonasi. Kaitanya dengan pendidikan multikultural, masih tetap bisa dijalankan meskipun siswa yang berpartisipasi merupakan siswa se zona. Terlebih Indrapangastuti (2014: 13) mengungkapkan: "peran guru dalam pelaksanaan pendidikan multikultural meliputi: membangun paradigma keberagaman inklusif di lingkungan sekolah, menghargai keberagaman bahasa di sekolah, membangun sikap sensitif gender di sekolah, membangun pemahaman kritis dan empati terhadap ketidakadilan serta perbedaan sosial, membangun sikap anti diskriminasi etnis, menghargai perbedaan kemampuan dan menghargai perbedaan umur".

Dari pernyataan di atas, maka pendidikan multikultural juga bisa diterapkan bersamaan dengan kebijakan zonasi. Terlebih sisem zonasi menghasilkan input siswa yang beragam, sehingga peran guru dalam pendidikan multikultural di atas dapat dilaksanakan. Mendukung pernyataaan sebelumnya Rohman \& Ningsih (2018) mengungkapkan: "Dengan penanaman pendidikan multikultural yang benar akan menghasilkan generasi muda di era revolusi industri 4.0 yang kreatif, inovatif, serta generasi yang berkarakter, berintegritas dan menjunjung tinggi toleransi sesuai identitas nasional bangsa Indonesia". Sehingga keberagaman siswa yang dihasilkan dari sistem zonasi dapat mendukung pembelajaran multikultural dan tidak mengurangi bahkan merusak kebhinekaan.

\section{SIMPULAN}

Dari hasil penelitian yang telah dilakukan, kesimpulan yang didapat ialah : (1) zonasi memudahkan akses layanan pendidikan, (2) zonasi memeratakan kualitas sekolah, (3) zonasi menurunkan kualitas sekolah, (4) zonasi tidak cocok ditetapkan di tingkat SMA, (5) sistem zonasi membatasi siswa memilih sekolah, (6) kebijakan zonasi harus disertai pemerataan sarana dan prasarana pendidikan, dan (7) zonasi merusak kebhinekaan. Perspektif-perspektif tersebut masing-masing muncul berdasarkan pemahaman, perasaan dan pengalaman yang telah dialami dengan kebiajkan sistem zonasi.

\section{DAFTAR RUJUKAN}

Amirin, T. M., Wijayanti, W. \& Jabar, C.S.A. 2016. Kondisi Insani dan Material Sekolah Menengah Negeri "Pilihan Kedua” Di Kota Yogyakarta. Jurnal Penelitian Ilmu Pendidikan, 9 (1), 1-11.

Andini, N. 2009. Analisis Pengaruh Persepsi terhadap Keputusan Orang Tua Murid Memilih Jasa Pendidikan di SD IT Bina Insani Semarang. Skripsi Tidak Diterbitkan. Semarang: Fakultas Ekonomi Universitas 
Diponegoro.

Bunar, N. 2010 The Controlled School Market and Urban Schoolsin Sweden. Journal Of School Choice: International Research And Reform, 4 (1), 47-73.

Creswell, J. W. 2015. Penelitian Kualitatif \& Desain Riset Memilih Diantara Lima Pendekatan Edisi Ketiga. (Terjemahan Ahmad Lintang Lazuardi). Yogyakarta: Pustaka Pelajar. (Edisi Asli Diterbitkan Tahun 2013 Oleh SAGE Publication, Inc.).

Cummings, W. K. 2008. Policy Options For Access and Equity in Basic Education. Dalam William K. Cummings \& James H. Williams (Eds). Policy-Making For Education Reform In Developing Countries : Policy, Options, And Strategy. USA: Rowman \& Littlefield Education

Ferry, M. 2018. Manajemen Peningkatan Mutu Sekilah di Sekolah Menengah Pertama Negeri 8 Yogyakarta. Skripsi Tidak Diterbitkan. Yogyakarta: FIP UNY.

Indrapangastuti, D. 2014. Praktik dan Problematika Pendidikan Multikultural di SMK. Jurnal Pembangunan Pendidikan Fondasi Dan Aplikasi, 2(1), 13-25.

Kisruh PPDB dan Sistem Zonasi 'Dadakan' dari Mendikbud. Detiknews. (Online) (Https:/News.Detik.Com/ Berita/D-3556024/Kisruh-Ppdb-Dan-Sistem-Zonasi-Dadakan-Dari-Mendikbud). Diakses 4 Januari 2014.

Liu, Y. 2017. The Equality of Distribution of Education Resources-The Case Of 96 Universities in The US. Open Journal Of Social Sciences, 5(1), 180-190.

Mandic, S., Et. Al. 2017. Adolescents' Perceptions of Cycling Versus Walking to School: Understanding The New Zealand Context. Journal of Transport \& Health, 4, 294-304.

Mandic, S., Et. Al. 2017. "I Wanted To Go Here": Adolescents' Perspectives on School Choice. Journal of School Choice, 12 (1), 98-122.

Menyoal Anomali Hasil Penerimaan Peserta Didik Baru SMA 2018. Katadata.Co.Id. (Online), (Https://KatadataCo. Id/Analisisdata/2018/07/17/Menyoal-Anomali-Hasil-Penerimaan-Peserta-Didik-Baru-Sma-2018). Diakses 4 Maret 2019

Nepal, B. 2016. Relationship Among School's Infrastructure Facilities, Learning Environment And Student's Outcome. International Journal of Research in Social Science and Humanities Research. 2 (5), 44-57.

Perdu, R. R., \& Sheetz S.D. 2008. Quality System Management and Education in Service Environments. Dalam Bill Hefley \& Wendy Murphy (Eds). Service Science Management and Enginering Education For 21st Century. New York: Spinger.

Permendikbud Nomor 17 Tahun 2017 Tentang Penerimaan Peserta Didik Baru pada TK, SD, SMP, SMA, SMK, atau Bentuk Lain yang Sederajat.

Permendikbud Nomor 14 Tahun 2018 Tentang Penerimaan Peserta Didik Baru pada TK, SD, SMP, SMA, SMK, atau Bentuk Lain yang Sederajat.

Permendikbud Nomor 51 Tahun 2018 Tentang Penerimaan Peserta Didik Baru pada TK, SD, SMP, SMA, SMK, atau Bentuk Lain yang Sederajat.

Raharjo, S.B. \& Yuliana, L. 2016. Manajemen Sekolah untuk Mencapai Sekolah Unggul yang Menyenangkan: Studi Kasus di SMAN 1 Sleman Yogyakarta. Jurnal Pendidikan dan Kebudayaan, 1 (2), 203-217.

Rohman, A. \& Ningsih, Y. E. (2018). Pendidikan Multikultural: Penguatan Identitas Nasional di Era Revolusi Industri 4.0. Prosiding Seminar Nasional Multidisiplin. 1 (1), 44-50.

Safarah, A. A. \& Wibowo, U. B. 2018. Program Zonasi di Sekolah Dasar sebagai Upaya Pemerataan Kualitas Pendidikan di Indonesia. Lentera Pendidikan, 21 (2), 206-213.

Saporito,S. 2017. Shaping Income Segregation in Schools: The Role of School Attendance Zone Geography. American Educational Research Journal. XX(X), 1-33.

Sugiyono. 2012. Desain Penelitian Kuantitatif, Kualitatif, dan R \& D. Bandung: Alfabeta.

Ten Step to Equity in Education. Oecd.Org. (Online) (Https://Www.Oecd.Org/Education/School/39989494.Pdf). Diakses 4 Januari 2019.

What are School Attendance Zones?. (Online), (Https://Support.Narrpr.Com/Hc/En-Us/Articles/204963410What-Are-School-Attendance-Zones-). Diakses 4 Januari2019. 